\title{
The carbohydrate composition and nutritive value of forages
}

\author{
Maija-Liisa Salo \\ Department of Animal Husbandry, University of Helsinki, 00710 Helsinki 71
}

\begin{abstract}
The carbohydrates of forages, their digestibility, the relationship between composition and the development stage in grasses and legumes, and the dependence of nutritive value on composition are examined.
\end{abstract}

\section{Carbohydrates and their digestibility}

The carbohydrates of forages can be divided into two main classes: the cellular carbohydrates and the structural or cell-wall carbohydrates. The division is an apt one in regard to nutrition physiology, since animals are able to digest the substances of the first category with the aid of their own enzymes, but those of the second only with the aid of microbes.

The cellular carbohydrates are: a) Monosaccharides (glucose and fructose). b) Sucrose. c) Oligosaccharides, which occur in forages only in very small amounts.

d) Fructosans, water-soluble polysaccharides, which are common in grasses but are not found in legumes. e) Starch, which occurs in forages only in traces or not at all.

The structural carbohydrates are hemicellulose and cellulose. Hemicellulose, a collective term for the non-cellulose structural polysaccharides, is composed of various polysaccharides differing in composition and digestibility. In general, hemicellulose is more susceptible to acid and alkali hydrolysis than cellulose. The main components of hemicellulose are xylose in grasses and uronic acids in clovers. Other consituents are arabinose, galactose and glucose. According to the main component one speaks of xylans, arabans, etc. though monosaccharides seldom form pure polymers.

Hemicellulose is digested better than cellulose, except for xylans, which are the least digestible polysaccharides in forages. Hence it would be desirable to analyse forages also for xylans. No simple method is known, however.

The term pectin is used in defining the fraction of hemicellulose that is soluble in a slightly acidic solution and is precipitated from it by ethanol. The components are galacturonic acid, arabinose, glactose and glucose. The amount of pectin in forages is fairly low. 


\section{Fig.1. The main components of forages}

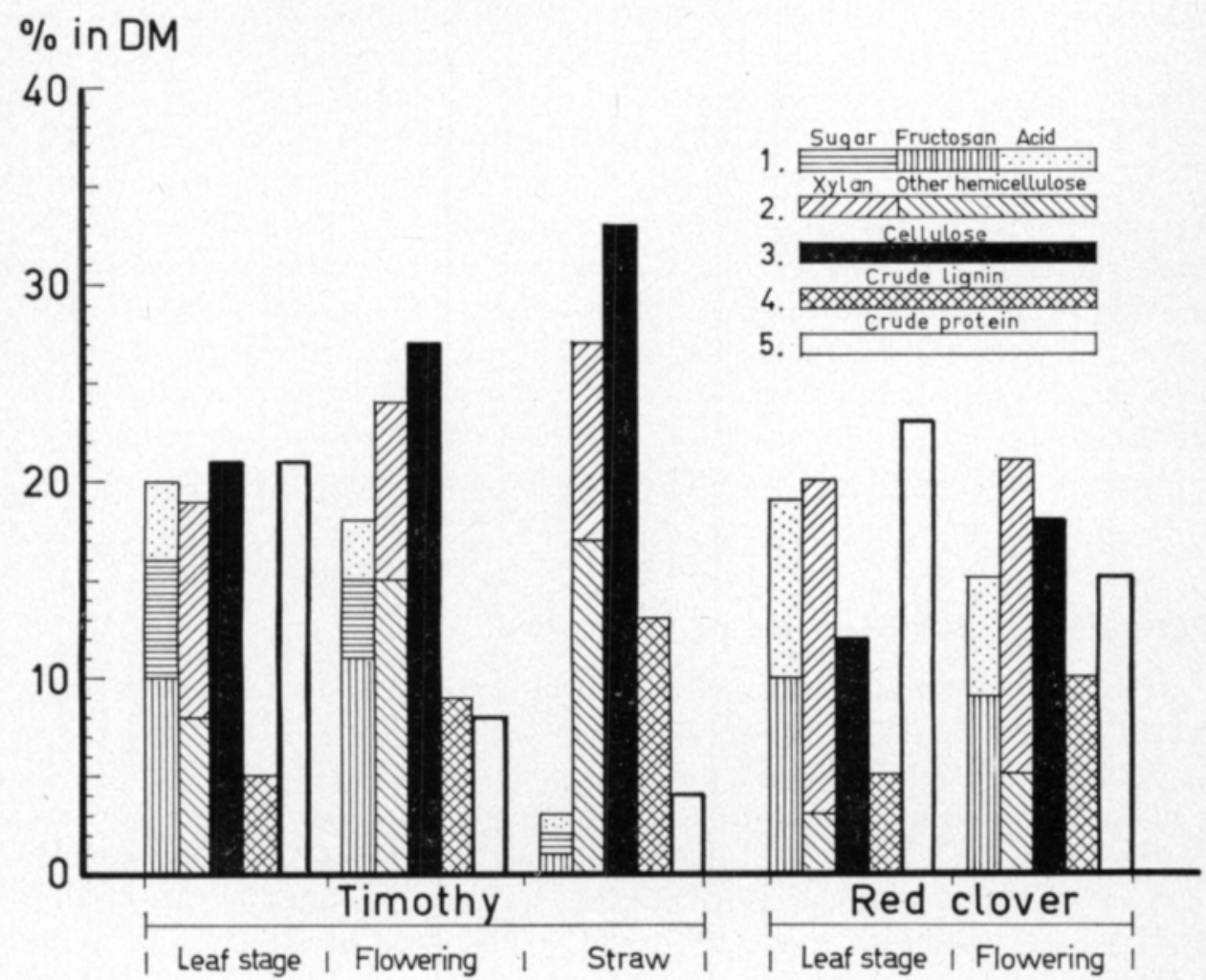

Lignin, an aromatic substance, is commonly determined along with the structural carbohydrates. It occurs in cell-walls together with polysaccharides and is very poorly or not at all digestible. As the plant ages, the content of both lignin and xylan increases, thus decreasing the digestibility of forages. The digestibility of grasses is also thought to be lowered by the presence of silica.

\section{Relationship between composition and the development stage in grasses and legumes}

The composition and consequent nutritive value of forages depends primarily on the growth stage. Other important factors are the plant species, climatic conditions and application of fertilizers. Figure 1 shows the changes in the composition of timothy and red clover as the plant develops from the leaf stage to the flowering and straw stages. The values shown are for the latitude of Helsinki, and are rounded-off averages. It may be noted that the sugar fructosan content, in particular, varies greatly with climate.

The xylan and lignin content of timothy nearly doubles as the plant develops from the leaf stage to the flowering stage, and thus the proportion of xylan in hemicellulose is increased still further. The content of cellulose does not rise as 
sharply. At the same time the protein content decreases markedly, while the percentages of the other cellular substances remain virtually unchanged. An almost total absence of cellular content and a high percentage of lignin characterize grasses at the straw stage.

The composition of red clover differs significantly from that of grasses. Fructosans are absent and the content of water-soluble carbohydrates is therefore fairly low. On the other hand, the percentage of plant acids - mainly malic and glycerolic acids - is more than double that of grasses. In both species the acids occur primarily as salts. The hemicellulose of clovers differs greatly in composition from that of grasses: nearly half of it consists of uronic acids and the amount of xylans is low. Consequently, the hemicellulose of clover is more digestible than that of grasses. Furthermore, the content of cellulose is half that of grasses, while that of lignin is equal in the twc species.

\section{Dependence of nutritive value on composition}

The energy value of forages depends on the utilization rate and the voluntary intake by animals. The net energy value of feeds is well illustrated by the digestibility coefficient. Because the determination of digestibility in vivo is complicated, various laboratory methods have been developed to take the place of in vivo trials. At present the in vitro method - the incubation of samples in the rumen fluid - is considered the best way of predicting the digestibility. The cellulase method is a simplified and standardized variation of it, where a commercial enzyme preparate is used instead of rumen fluid. The results of this simplified method are also found to correlate well with in vivo results, although the digestive effect of the enzyme preparates is not as good as that of the rumen fluid. The common in vitro method is, however, better established and therefore more reliable.

Of the chemical entities, the digestibility is best predicted by the amount of lignin although not as well as by the two biological methods mentioned above. Moreover, the determination of lignin is laborious and different variations of the method do not give the same results. Various fibre complexes - crude fibre, neutral detergent fibre (NDF), and acid detergent fibre (ADF) - are poorer than lignin as parameters of digestibility, although better than cellulose and hemicellulose. The percentages of various cellular substances, on the other hand, vary so much that they cannot be used in predicting the digestibility. When the material is homogenous there may be a good correlation between the crude protein content and the digestibility.

The high nutritive value of the feed implies further that the voluntary intake is copious. The voluntary intake is determined to a great extent by the digestibility, but the bulk factor is also of some significance. Thus the voluntary intake of clovers is known to exceed that of grasses, though the digestibility is the same. This difference has been explained by the faster digestibility of the cell-wall polysaccharides of the clovers in the rumen, and hence the smaller bulkiness. As Figure 1 shows, the cell-wall compositions of these two plant species are very different. 
Probably the cow also appreciates the texture and taste of the feed. The clover is softer than grasses, because it contains hardly any of the silica that makes the leaves of grasses coarse. The sugar, in turn, makes the feed palatable, and fresh forages up to the flowering stage contain plenty of sugars. In sugar content the clovers take second place to the grasses, but at the same time they have a very high content of plant acids, which also may increase the palatability.

\section{REFERENCES}

SaLo, M.-L. 1965. Determination of carbohydrate fractions in animal foods and faeces. Acta Agr. Fenn. 105: 1-102.

- - 1965. The composition of pasture grasses at the University Farm Viik. J. Scient. Agric. Soc. Finl. 37: 135-147.

- - 1973. Analytisk bestämning av vallväxternas fodervärde. NJF:s symposium Tune 29. - 30. Okt. Repr. 18 p.

- $-\&$ Kotilainen, K. 1969. Determination of free and combined plant acids. J. Scient. Agric. Soc. Finl. 41: 277-289.

- - - NYKäNen, A. \& Sormunen, R. 1975. Nurmikasvien koostumus, pepsiini-HCl-liukoisuus ja in vitro-sulavuus eri kasvuasteilla. J. Scient. Agric. Soc. Finl. 47:480-490.

Terry, R. A., Osbourn, D. F., Cammell, S. B. \& Fenlon, J. S. 1974. In vitro digestibility and the estimation of energy in herbage. Proc. 5th Gen. Meet. Eur. Grassl. Fed. Uppsala.

Ms received January 3, 1977

\section{SELOSTUS}

\section{Korsirehujen hiilihydraattikoostumuksesta ja rehuarvosta}

Maija-Lirsa Salo

Yliopiston kotieläintieteen laitos, Helsinki

Kasvuaste vaikuttaa oleellisesti korsirehujen koostumukseen ja rehuarvo vuorostaan riippuu koostumuksesta. Erityisesti ligniini- ja ksylaanipitoisuuden nousu alentaa sulavuutta ja edelleen rehuarvoa. Korsirehujen sulavuus voidaan määrittää varsin tarkasti in vitromenetelmällä ja saadun tuloksen (D-arvo) sekä raakaproteiinipitoisuuden perusteella voidaan laskea energia-arvo märehtijöillä. Heinäkasvien ja puna-apilan sulavuus on samalla kasvuasteella suunnilleen sama, mutta apilan täyttävyysvaikutus on pienempi; apilan ksylaanija selluloosapitoisuus on näet suhteellisen alhainen ja sen vuoksi apila sulaa ja kulkee etumahojen läpi heinäkasveja nopeammin. 